\title{
Socio-economic impact of shopping centres in Gauteng, South Africa
}

\author{
B F van Niekerk \\ C E Cloete \\ Department of Construction Economics, University of Pretoria, \\ Pretoria, South Africa
}

\section{Keywords}

Socio-economic impact, retail real estate, shopping centres, employment, environment, income

\begin{abstract}
Purpose: Shopping centres have become an integral part of the built environment in South Africa, in many cases causing marked socio-economic effects, both positive and negative. The present study attempts to provide a better understanding of the multi-faceted effects that shopping centres manifest in the community through providing an overview of the socio-economic impact of shopping centres in Gauteng, South Africa.

Methodology: Due to the complex nature of socio-economic systems, the method selected to conduct the data analysis is the thematic analysis approach. Thematic analysis is a process used to identify the underlying themes of the data that has been collected by utilising a software program (Nvivo 12 Pro) to assist with the thematic analysis process. Upon identifying the underlying themes present within the data, initial codes and keywords identified were then organised into broader themes. To identify prominent themes the keywords are grouped into categories, and a ranking is given based on the frequency which the categories appear in the sample literature.

Results: The top three socio-economic impacts of shopping centres on their communities were found to be employment (jobs created), the improvement of local infrastructure. and the additional income generated in the local community.

Originality: Although a number of studies have investigated various socio-economic impacts of shopping centres, the use of thematic analysis offers a systematic perspective in this topic.

Practical implications: Developers of shopping centres should justify the merits of proposed developments by emphasising the effect on the creation of jobs, improvement of local infrastructure and its environmental sustainability and the additional income generated in the relevant communities.
\end{abstract}

Acknowledgement

The second author (Chris Cloete) acknowledges the financial support of the South African Council of Shopping Centres through endowment of the SACSC Chair in Shopping Centre Studies at the University of Pretoria

\section{Introduction}

There is a direct relationship between the economic impact and the social impact of shopping centre developments in that the majority of shopping centres contribute towards the social and economic wellbeing of the community. Shopping centres are utilised for both socio-cultural and economic purposes and "...commonly include a wide range of retailing and entertainment facilities. They are places for recreation, exercising and socialising, as well as for purchasing goods and services. Many retail complexes have an integrated role, often in association with an existing business area, as the focus for the suburb or suburbs they serve ..." (Taylor, McClintock \& Buckenham, 2003, p. 148). With the integration of social aspects and shopping, the shopping centre environment is becoming a larger part of the culture within a community. The local community benefits from the presence of shopping centres as they play a role in the creation of jobs and act as economic stimulators (Williams, 1992; McGreevy, 2016).

The shopping centre industry is one of the primary facilitators of retail sales that drive private consumption which, in turn, drives Gross Domestic Product (GDP) (SACSC, 2017). They are one of the largest employers in South Africa, accounting for approximately $21 \%$ of formal sector jobs (Malgas et. al, 2017, p. 2). Now more than ever, the sales, income and employment generated by shopping centres have increasingly evolved to have an impact greater than just retail convenience. Shopping centres also act as a catalyst that stimulates their local economy by providing employment opportunities which, in turn, 
contributes to income per capita for the community and generates revenue for the local and national government.

Some of the major benefits of the development of shopping centres are direct employment, indirect employment and capital investment (Robertson \& Fennell, 2007).

Direct employment. The larger the centre the more jobs will be created in the area. These include staff that work in the shops, security guards, cleaning personnel, maintenance personnel as well as the jobs during construction of the centre. Without the centre these job opportunities would not be available. Regional or super regional centres can create thousands of new job opportunities. The Mall of Africa in Gauteng, for example, opened in 2016 with a GLA of 131000 square metres. It estimated that the Mall of Africa created 4500 permanent job opportunities (Mall of Africa, 2016). In addition to permanent employment, shopping centres also create significant seasonal employment for example, over Christmas and new year periods when trading increases substantially. In South Africa the chopping centre industry has more than 600000 permanent jobs (BusinessTech, 2016).

Indirect employment. Shopping centres also create indirect employment by the spend of individual business located in the centre on goods, supplies and services. Further employment is also created when the employees of shopping centres or supplying firms spend their wages. This is known as a multiplier effect. This multiplier effect is however lower than other forms of development such as manufacturing. Further employment is also created by expenditure of visitors to these large centres but takes place outside the centre itself, namely, jobs by way of transportation i.e. in busses and taxis as well as filling stations and other nearby shops. These are visited because of a trip to the shopping centre. According to BusinessTech (2016) more than 500000 indirect jobs are created by the shopping centre industry in South Africa.

Capital investment. Shopping centres bring substantial private capital investment to areas that previously has little, namely, new buildings as well as significant improvements to the surrounding infrastructure. These investments are ongoing because centres are constantly extended and refurbished, shops refitted, and infrastructure upgrades.

In addition to these benefits, it is fairly common that shopping centres implement corporate social initiatives (utilisation of business resource to benefit the local underprivileged communities in which the company operates to develop/implement a behavior change intended to improve community wellbeing), contribute to skills transfer (training a new employee to perform a task or skill for growth, sustainability and prosperity) and investing in education and training, amongst others. A recent example of these positive impacts is the expansion in 2017 of the Ballito Junction Regional Mall in Kwazulu-Natal from 10 $000 \mathrm{sqm}$ to $80000 \mathrm{sqm}$. The mall worked closely with the KwaDukuza Municipality to ensure that local jobseekers could benefit from the jobs created during its construction as well as the sustainable jobs which it has created for its ongoing operation. Staff for the mall were sourced from the nearby areas of Ndwedwe, Shakaskraal, Stanger and Maphumulo, which traditionally would focus on farming/agricultural activities.

More than 2000 jobs were created during the construction of the mall from January 2015 to March 2017, 1500 jobs were created during the fit out of individual stores and 1200 jobs were created post construction. Based on the appointment of service providers to attend to cleaning, security, landscaping and refuse management, centre management was instrumental in the appointment of 117 staff in these areas.

As a contribution to social upliftment, an early learning child educational centre that was built in Ndwedwe in the Build the Future Project paved the way for long term future engagements with a variety of projects. In addition, a Community Platform was developed for local disadvantaged communities to be able to generate an income via a Community initiative retail outlet at the Ballito Junction Regional Mall.

The development of shopping centres may also have negative effects, however. There is generally a negative impact on the surrounding small informal and formal township retailers when a new shopping mall is developed. Research by Ligthelm shows a $47 \%$ decline in the number of small businesses in the immediate area during the first six months after the opening of a new mall (Ligthelm, 2012). Almost three out of five small businesses retailers experience a decline in their profitability, turnover and product range. Only a small portion $(1 \%-4 \%)$ reported better business conditions. Similar effects were found in a 
study of the impact of shopping centre development on informal and small businesses in Lagos, Nigeria (Ikadeh 2017). Semi-structured interviews with 30 informal and small business owners as well as 100 shoppers were conducted in five different shopping areas, including the areas around the two major shopping centres in Lagos. Most of the informal and small businesses were struggling to survive. Different strategies have, however, been developed for competing against the giant retailers in the shopping malls, including the provision of different types of food and quantities of goods not provided in the formal shopping centres.

The presence of shopping centres in especially economically deprived areas can lead, on the one hand, to 'aspirational' shopping, motivating shoppers to improve their financial well-being to be able to afford products and services that previously had been unknown or out of their financial reach. On the other hand, shoppers may become envious and take out unsecured loans, creating artificial buying power and financial distress.

\section{Research Methodology}

To provide an overview of the socio-economic impact of shopping centres, a critical survey of existing literature is conducted with the aid of a computer programme (Nvivo 12 Pro) to assist with the analysis of the sample and the identification of prominent socio-economic aspects, which is followed by a discussion of each of the aspects. Vital statistics are collected from Statistics South Africa, the South African Council of Shopping Centres (SACSC) and other internet sources.

\section{Sampling}

Due to the difficulty in obtaining sources for the sample, the convenience sampling strategy is used to identify reports, journal articles and conference papers that are applicable to shopping centres. Furthermore, for the source to be part of the sample, each source needs to meet the selection criteria as listed below:

- Must be applicable to retail real estate, shopping centres or malls.

- Needs to address a variety of socio-economic aspects affected by retail real estate.

- May not be older than 10 years to remain relevant to the times.

The sample size is determined by way of data saturation - which means that at some point, by adding additional sources to the sample, no new information will emerge. Existing literature suggests a sample size of twelve be sufficient (Guest, Bunce, \& Johnson, 2006 \& Latham, n.d. \& Sim et. al., 2018). The initial analysis uses twelve sources in the sample. Three additional sources are added and analysed to ensure that no new themes are missed as per the data saturation method. No new themes emerged from the analysis of the sources and therefore fifteen samples were considered sufficient.

\section{Data Collection}

Sources were collected through online platforms such as Google Scholar and the University of Pretoria's online library. A data collection process similar to the one described by Salkind (2012) has been adapted for the purpose of the study, where initially a search was done to find potential sources to add to the sample.

The initial search found more than thirty-seven socio-economic aspects that are influenced by shopping centres identified across thirty-one sources. Fifteen sources were eliminated by using the sample selection requirements.

\section{Data Analysis}

By utilising a software program (Nvivo 12 Pro) to assist in the thematic content analysis process, the identification and coding process is made easier. The advantages of using this process is that it is a more flexible method of data analysis and it provides a great amount of detail in the collected data. However, due to the detail and wealth of data, it can become quite complex and time consuming (Braun \& Clarke, 2006).

\section{Findings} Ranking

To identify the top three socio-economic aspects, a ranking system was created to determine the frequency which the aspects appear in the sample. Where the Frequency of Aspect indicates how many 
sources in the sample refer to each socio-economic aspect ( 1 frequency per source) and the Frequency of Reference refers to the number of times the identified socio-economic aspect is referenced in the sample.

\begin{tabular}{|l|l|l|l|}
\hline Ranking & Socio-Economic Aspect & Frequency of Aspect & Frequency of Reference \\
\hline 1 & Employment & 13 & 46 \\
\hline 2 & Environment & 11 & 30 \\
\hline 3 & Income & 9 & 27 \\
\hline 4 & Recreation/Leisure & 6 & 20 \\
\hline 5 & Safety and Security & 5 & 8 \\
\hline 6 & Culture & 6 & 10 \\
\hline 7 & Tax & 6 & 4 \\
\hline 8 & Education & 2 & 4 \\
\hline 9 & Tourism & 2 & 2 \\
\hline 10 & Crime & 1 & 1 \\
\hline
\end{tabular}

\section{Shopping Centre Numbers}

Table 1: Frequency of Socio-Economic Aspects

The SACSC Shopping Centre Directory indicates that South Africa currently has a combined 23.4 million square meters of Gross Lettable Area (GLA) across 1266 shopping centres. When considering the South African population, this gives a GLA of approximately 418 square meters for every 1,000 people (SACSC, 2019).

In addition, there were approximately 68 shopping centres in the development pipeline as of 2017 with a combined GLA of roughly 1.9 million square meters that would be added to the existing retail space - estimated completion by the end of 2021. That said, retail stock has grown by an average of $17.3 \%$ year on year between 2010 and 2017 (SACSC, 2017).

\begin{tabular}{|l|l|l|}
\hline Province & Number of Centres & GLA $\left(\mathrm{m}^{2}\right)$ \\
\hline Eastern Cape & 72 & 1322955 \\
\hline Free State & 51 & 793640 \\
\hline Gauteng & 506 & 10703878 \\
\hline Kwa-Zulu Natal & 183 & 3107048 \\
\hline Limpopo & 87 & 1302346 \\
\hline Northern Cape & 17 & 257200 \\
\hline Mpumalanga & 93 & 1600944 \\
\hline North West & 60 & 967045 \\
\hline Western Cape & 196 & 3295509 \\
\hline Total & 1266 & 23358103 \\
\hline
\end{tabular}

Table 2 : SACSC Shopping Centre Directory Numbers (Source : SACSC, 2019) 
Based on the shopping centre numbers, informed estimates can be made regarding employment and employment income earned in the shopping centre industry across South Africa and Gauteng.

\section{Employment}

The approximate 1.9 million square meters of GLA in the development pipeline in South Africa includes the development of centres ranging in size from neighbourhood shopping centres to minor regional shopping centres (SACSC, 2017).

If the developers rule of thumb is to be used - one million rand in construction cost equals one construction worker - the initial number of employment opportunities range between $16000-24000$ in South Africa or 7200 - 11000 in Gauteng for the period 2017 - 2021.

Further employment opportunities are generated from the management and operations of a shopping centre. For every retail employee there is between 38 and 40 square meters of retail space. This translates to a contribution of between 584000 - 615000 direct permanent jobs to the labour market, of which approximately $267000-282000$ are in Gauteng.

The multiplier effect also needs to be considered as it is the result of an increase in spending which produces an increase in income and consumption that is greater than the amount that has been spent. A study done for the city of Johannesburg Metro by the Trade \& Industrial Policy Strategies (2015) found that for every R1 000000 in sales generated 3.91 additional jobs were created.

\section{Income}

The local economy is stimulated by the additional income generated from the construction of a shopping centre and then further by the management and operations thereof. The construction industry generates 7200 - 11000 jobs. At an average salary of R16 500/month (R198000/annum) per construction worker (Wasserman, 2019) R2 178000 000/annum is generated in employment earnings for construction workers in the Gauteng region.

This equates to approximately R258 - R394 million generated in government revenues from personal income tax from the construction of the shopping centres in Gauteng. Further government revenues are generated from the retail employees that manage and operate the shopping centres which can generate as much as R8.36 billion in revenue for the South African Government.

\section{Environment}

A shopping centre can have a significant impact on its physical and commercial environment. The larger shopping centres attract a significant number of shoppers to an area which creates an influx of traffic. With the influx of traffic, improvements to road infrastructure is required to cater for the additional traffic flow. The larger the centre, the greater the need for the improvement of infrastructure to accommodate the increase in traffic. The improved infrastructure not only has a positive effect on the local community, it also influences perception of an area which can potentially attract additional investments (Ligthelm, 2008) which may further snowball into an economic catalyst for a commercial node.

Larger retail centres also form a natural focal point or become a key landmark for a community. "... (N)ot only (do they) dramatically improve the physical and social fabric of the urban environment, but also regenerate economic fortunes and improve local quality of life in the process." (ICSC, 2017, p. 15). Yet at the same time they can be one of the biggest culprits when it comes to the consumption of electricity, waste creation and carbon emissions. "The environmental impact of mass consumables is enormous and would far outweigh the impacts of the buildings they inhabit." (Mate, 2012, p. 3).

To combat the environmental impact of these consumables, many shopping centre owners, developers and retailers implement sustainability initiatives by: Making use of energy efficient building designs that maximise the use of natural light; using energy efficient building materials; making use of renewable energy such as solar power generation; and taking part in recycling initiatives (water and waste).

In Gauteng there are currently two green star rated shopping centres (Menlyn Maine and The Villa Mall) and an ever-growing number of shopping centres putting green practices into place (i.e. solar power, water, and waste management). 


\section{Discussion and conclusions}

The socio-economic aspect most often discussed is employment, and it appears more frequently than any of the other socio-economic aspects in the sample literature. It is easy to understand why since the retail industry (formal and informal sectors) provided approximately $23.6 \%$ of the jobs to the working population in the first quarter of 2019.

Any new development will require both skilled and unskilled labourers during the construction process. In an area with higher unemployment rates, the construction process will bring an immediate boost to the local economy through employment. This can be attributed to contractors making use of local labourers during the construction process.

Following the general rule of thumb of one construction worker for every one million rand in construction cost, the number of jobs created by the construction phase of shopping centres in the country ranges between 16000 - 24000 jobs for the period 2017 - 2021. Gauteng estimates are difficult - however, assumptions can be made based on the fact that Gauteng has the highest concentration of shopping centres ( $45.8 \%$ of the total GLA) in South Africa. It can be assumed that the construction of shopping centres in Gauteng creates between 7200 - 11000 jobs.

Direct employment opportunities are initially provided through the construction phase of shopping centres, followed by job creation through the operations and management of the centres. Accordingly, operations and management of shopping centres in Gauteng provide between 262000 and 282000 jobs based on the GLA figures and the estimate that there is one retail employee per 38 - 40 square meters of GLA.

The physical environment is the aspect that is most visibly affected by the development of shopping centres. It is a generally accepted norm that larger shopping centres tend to attract a more economically active population and can sometimes rejuvenate or gentrify a neighbourhood. The three most important ways that shopping centres may affect their environment are:

The physical environment and its surroundings are affected by the improvement of local infrastructure. New retail developments would attract large amounts of potential shoppers and this would naturally increase the traffic influx in an area. To avoid congestion, road infrastructure is improved. This improved infrastructure and influx of traffic attracts "street vendors" (people selling their wares on the side of the road and at traffic lights). Retailers further impact the environment through the beautification of an area in an attempt to attract additional shoppers.

Retail real estate also affects its commercial environment. The improved infrastructure makes an area attractive to retailers and business owners as a result of the improved access to an area. Over time the formation of an agglomeration is created as shopping centres assist in the stimulation of the local economy by attracting additional retailers and large amounts of potential shoppers to an area and increasing the tax base of that community.

The shopping centre industry is taking environmental concerns seriously by promoting environmentally sustainable initiatives such as solar power generation; green building design; and waste and recycling management. Furthermore, the industry is promoting corporate citizenship through corporate social responsibility campaigns and good business practices by becoming more environmentally sustainable.

The employment generated by shopping centres increases the level of income per capita in the local community which has a ripple effect on consumption (consumer spending) and retail revenue. Income is further affected by the plough-back of spending into the local economy as a result of the increased disposable income.

During the construction phase there is an immediate, albeit temporary, boost to the income generated within the boundaries of the local economy, which, in turn, will temporarily increase disposable income. Based on the findings in the study, the construction industry in Gauteng generates close to R8.4 billion in income earnings and nearly R400 million in tax revenue for the Government.

After construction has been completed, there remains a permanent increase in income as a result of the creation of permanent jobs. The extent of this increase will depend primarily on the size and type of the shopping centre constructed. In addition, revenues will be generated for local businesses as the newly employed will use a percentage of their income to support local businesses. 
Figure 1 is a summary of the top three aspects that are influenced by shopping centres.

\section{Limitations and direction for future studies}

The analysis was done on the basis of saturation sampling, employing a total of fifteen sources. These sources were identified from existing international literature less than ten years old and analysed by means of thematic content analysis.

Although shopping centres around the world have a number of common characteristics, it is conceivable, and indeed likely, that the impact of a centre can differ in different societies. For example, the impact on employment of a centre in a developed country where construction may be less labourintensive, is probably less than in the case of a developing country where construction is likely to be more labour-intensive. Also, the impact on the local economy may be different in a society with a sophisticated tenure and taxation system than in a society where this is not the case. Given the effect of the changing nature of shopping (e.g. e-commerce, leisure and food retailing) on shopping centres, it is also likely that the impact of a shopping centre may in future be less pronounced in certain aspects and more pronounced in other aspects.

These factors will make generalisations more difficult and will require place- and time-specific research to determine the actual impact of a shopping centre.

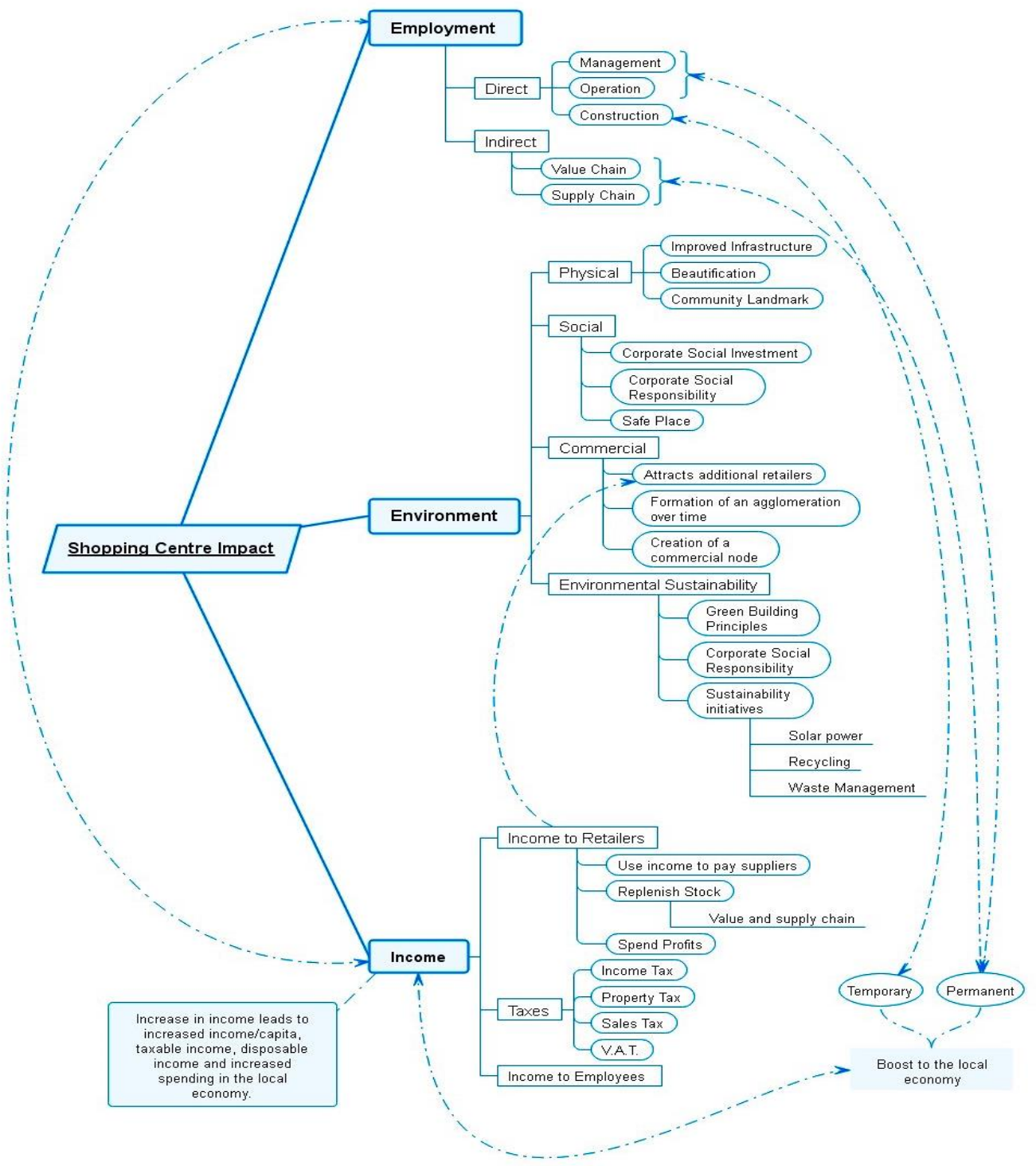

Figure 1: Primary Impact of Shopping Centres 


\section{Recommendations and policy implications}

It is recommended that the potential impact of a proposed shopping centre be determined with due cognisance of the unique characteristics of the specific society in which the centre is proposed. Generalisations from international findings may not be applicable in specific cases.

From a policy point of view, it should be required that the potential impact of a proposed shopping centre should be determined with special attention being given to the three aspects identified in this study, viz. employment, environment, and income.

\section{References}

Braun, V. \& Clarke, V., (2006). Using thematic analysis in psychology. Qualitative Research in Psychology, 3(2), pp. 77101.

BusinessTech, 2016. This is how many shopping malls are in South Africa. [Online] Available at:

https://businesstech.co.za/news/lifestyle/121847/this-is-how- many-shopping-malls-are-in-south-africa/ [Accessed 16 September 2019].

Guest, G., Bunce, A., \& Johnson, L. (2006). How many interviews are enough? An experiment with data saturation and variability. Field Methods, 18(1), 24. doi:10.1177/1525822X05279903.

ICSC, (2017). The Socio-economic Impact of European Retail Real Estate. ICSC Research. Available at:

https:/ / www.google.com/url?sa=t\&rct=j\&q=\&esrc=s\&source =web\&cd=2\&cad=rja\&uact=8\&ved=2ahUKEwjsy4f8vqLkAhWCYVAKHcn0AvcQFjABegQIEBAC\&url=https $\% 3 \mathrm{~A} \% 2 \mathrm{~F} \% 2 \mathrm{Fprch}$.org.pl\%2Fen\%2Fknowledge-base \%2F96-other-markets\%2F228-report-the-socio-economicimpact-of-european-retail-real estate-icsc\&usg=AOvVaw3eBr8IpS2W0Te1pe8R6uNL (Accessed 27 August 2019).

Ikadeh, M. (2018). The Impact of Shopping Centre Development on Informal and Small Businesses in Lagos, Nigeria. Unpublished MSc (Real Estate) mini-dissertation, University of Pretoria, Pretoria, South Africa.

Latham, J., n.d. Qualitative Sample Size - How Many Participants is Enough? Available at:

https://www.drjohnlatham.com/many-participants-enough/(Accessed 1 August 2019).

Ligthelm, A.A., (2008). The Impact of Shopping Mall Development on Small Township Retailers. South African Journal of Economic and Management Sciences, 11(1), pp. 37 - 53. doi:10.4102/sajems. v11i1.376.

Malgas B., Khatle, T. \& Mason R.B., (2017). Job creation in the South African retail sector. The Retailing and Marketing Review. Vol. 13 issue 1 (2017) Available at: https://www.researchgate.net/publication/323915696 (Accessed 12 September 2018).

Mall of Africa, 2016. News Article - Mall of Africa opens for business. [Online] Available at:

https://mallofafrica.co.za/news-article/mall-of-africa-opens-for-business/4 [Accessed 18 September 2019].

Mate, K., (2012). Remediating Shopping Centres for Sustainability, IE International Conference, 2012. Reinventing Architecture and Interiors: the past, the present and the future. Ravensbourne 28-29 March 2012.

McGreevy, M., (2016). “The Economic and Employment Impacts of Shopping Mall Developments on Regional and Peri-urban Australian Towns," Australasian Journal of Regional Studies, 22(3), pp. 402 - 434.

Robertson, J. \& Fennell, J., 2007. The economic effects of regional shopping centres. Journal of Retail \& Leisure Property, 6(2), pp. 149-170.

Salkind, N. J., (2012). Exploring research. $8^{\text {th }}$ edn. New Jersey: Pearson.

SACSC, (2017). Average shopping centre size on the rise. SACSC. Available at:

https:/ / sacsc.co.za/news/average-shopping-centre-size-on-the-rise (Accessed 12January 2019).

SACSC, (2017). Average shopping centre size on the rise. SACSC. Available at:

https:/ / sacsc.co.za/news/average-shopping-centre-size-on-the-rise (Accessed 12January 2019).

SACSC, (2019). SACSC Shopping Centre Directory 2019. SACSC, Sandton.

Sim, J., Saunders, B., Waterfield, J., \& Kingstone, T. (2018). Can sample size in qualitative research be determined a priori? International Journal of Social Research Methodology. pp. 1 - 16. Routledge. Available at:

https://www.researchgate. net/publication/324042278 (Accessed 1 August 2019).

Taylor, N., McClintock, W., \& Buckenham, B. (2003). Social Impacts of out-of-centre shopping centres on town centres: A New Zealand case study. Impact Assessment and Project Appraisal, 21(2) pp. 147- 153.

Unknown author, 2019. Unwelcome intruders: How malls make poor areas poorer. [Online] Available at:

https://www.news24.com/MyNews24/unwelcome-intruders-howmalls-make-poor-areas-poorer-20190225

[Accessed 18 September 2019].

Williams, C., (1992). The Contribution of Regional Shopping Centres to Local Economic Development: Threat or Opportunity? Area, 24(3), pp 283 - 288. Available at: http://www.jstor.org/stable/20003147 (Accessed 19 August 2018).

Wiid, J., \& Diggines, C., (2009). Marketing Research. Cape Town: Juta. 